\title{
Perancangan Robot Dengan Kemampuan Mencari, Mendekati, Dan Menggiring Bola Ke Gawang
}

\author{
Budi Santosa Haryanto ${ }^{1}$, Hadian Satria Utama ${ }^{1}$ dan Dali S. Naga ${ }^{2}$
}

\begin{abstract}
This design aims to create a robot that can search the ball, approach the ball, and keep the ball from the field/own goalpost towards the pitch area/the opponent's goalpost also pay attention to the position of the obstacles and the robot's position in the field. There are various movements such as looking for the ball, dribbling, and avoid the opponent. To be able to perform that movements the robot must be able to know what is the definition of the ball, the opponent, and goalpost. To know these objects then there must be a sensor that can read and that sensor is camera. The robot can know the object based on the different colors of each object caught by the camera. The capture of the camera then processed into a processor and the processor will determine the movement on the robot by sending current to the circuit driving the robot. Processor filters out the colors in turn at each color used. Processor then looks for the coordinates of the midpoint, and the area of the object detected. All values of the coordinates of the midpoint and the area of each color are used to determine the movement of the robot. Robot driving uses 3 driver motors DC, motors DC, and Omni wheels. The movements of the robot are going forward, rotating left/right, and standing still. The test results of the designed the robot successfully searched for the ball, approached the ball, kept the ball from the field/own goalpost towards the pitch area/the opponent's goalpost, and was prevented from going off the field.
\end{abstract}

Keywords: robot, wheels, football, motion, camera, processor.

\begin{abstract}
ABSTRAK: Perancangan ini bertujuan untuk membuat robot yang dapat mencari bola, mendekati bola, dan menjauhkan bola dari daerah lapangan/gawang sendiri ke arah daerah lapangan/gawang lawan dengan memperhatikan juga posisi halangan dan posisi robot di lapangan. Terdapat berbagai macam gerakan seperti mencari bola, menggiring bola, dan menghindari lawan. Untuk dapat melakukan gerakan-gerakan tersebut, robot harus dapat mengetahui apa yang dimaksud dengan bola, lawan, dan gawang. Untuk mengetahui bendabenda tersebut maka harus terdapat sensor yang dapat membacanya yaitu kamera. Robot dapat mengetahui benda yang dimaksud berdasarkan warna-warna yang berbeda dari setiap benda hasil tangkapan kamera. Hasil tangkapan kamera kemudian diproses ke sebuah pemroses lalu pemroses menentukan penggerak pada robot dengan mengirim arus pada rangkaian penggerak robot. Pemroses memfilter warna yang ingin dideteksi saja secara bergilir pada setiap warna yang digunakan. Pemroses kemudian mencari koordinat titik tengah, dan luas dari benda yang dideteksi. Nilai-nilai koordinat titik tengah dan luas dari tiap warna yang digunakan ini lah yang menentukan pergerakan robot. Penggerak robot menggunakan 3 buah driver motor DC, motor DC, dan roda omni. Pergerakan robot yang dapat dilakukan adalah maju, berputar tempat kanan/kiri, berputar mengelilingi bola kanan/kiri, dan diam. Hasil pengujian robot yang dirancang berhasil mencari bola, mendekati bola, menjauhkan bola dari daerah lapangan/gawang sendiri ke arah daerah lapangan/gawang lawan, dan menghindari luar lapangan.
\end{abstract}

Kata kunci: robot, roda, sepak bola, gerakan, kamera, pemroses.

\section{PENDAHULUAN}

$\mathrm{P}$ erkembangan robotika sangat pesat di negara-negara maju. Di Indonesia sendiri robotika cukup berkembang. Salah satu cara Indonesia dalam mengembangkan robotika adalah dengan mengadakan berbagai macam kontes robot. Salah satunya kontes yang di adakan di Indonesia adalah kontes robot sepak bola Indonesia. Kontes robot sepak bola di Indonesia sudah ada sejak tahun 2009 namun belum menggunakan pengolahan citra. Pada tahun 2012 barulah robot dipertandingkan seperti pertandingan sepak bola sesungguhnya dengan menggunakan aturan-aturan bermain seperti orang bermain sepak bola pada umumnya dengan menggunakan kamera untuk penglihatannya [1].

Dalam mendesain dan memrogram robot sepak bola tidaklah mudah, banyak yang harus dipelajari seperti kemampuan mendeteksi dan pergerakan robot. Berdasarkan masalah penentuan pergerakan robot yang harus dilakukan pada kondisi-kondisi tertentu, penulis merancang robot beroda yang menggunakan kamera untuk menentukan pergerakan robot dalam mencari, menggiring, menghindari suatu benda.

\section{DESKRIPSI KONSEP}

Robot yang dirancang berfungsi untuk mencari, menggiring bola, melewati halangan, dan mengarahkan bola ke gawang lawan. Terlebih dahulu harus dilakukan kalibrasi warna bola, robot, penghalang, gawang lawan dan gawang sendiri, dan lapangan. Setelah melakukan kalibrasi warna robot, bola, gawang dan penghalang harus diletakkan di dalam lapangan setelah itu robot baru diaktifkan. Pengaktifan robot dilakukan dengan cara menekan switch pada robot. Setelah aktif maka pemroses pada robot booting. Setelah booting selesai pemroses langsung menjalankan program secara otomatis sehingga robot memulai gerakannya sesuai rancangan.

Pergerakan robot ditentukan oleh hasil pemrosesan dari pemroses. Saat pemroses sudah aktif robot menangkap gambar dari kamera. Hasil tangkapan dari kamera diterima oleh pemroses berupa sinyal. Pemroses kemudian mengubah sinyal-sinyal dari kamera menjadi kumpulan nilai-nilai. Nilai-nilai ini menyatakan warna yang didapat oleh kamera setiap pixel. Kumpulan nilai-nilai pixel ini kemudian digabungkan membentuk suatu frame matriks yang berisi semua nilai-nilai dalam pixel. Pemroses lalu mengambil suatu rentang nilai tertentu saja sesuai warna yang ingin ditangkap pada frame tersebut.

\footnotetext{
${ }^{1}$ Program Studi Teknik Elektro, Fakultas Teknik, Universitas Tarumanagara

${ }^{2}$ Program Studi Teknik Informastika, Fakultas Sistem Informasi, Universitas Tarumanagara
} 
Pemroses lalu mendapat informasi-informasi berdasarkan warna yang ditangkap seperti posisi koordinat benda yang ingin dideteksi dan luas warna yang ditangkap terhadap suatu frame. Informasi-informasi inilah yang menentukan sinyal yang dikirim ke motor servo dan driver motor untuk menggerakkannya. Konstruksi keseluruhan robot dapat dilihat pada Gambar 1.

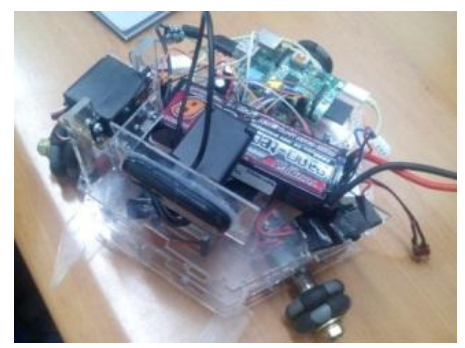

- Gambar 1. Konstruksi Keseluruhan Robot

Robot pertama diaktifkan dengan switch. Setelah robot aktif, robot memulai pencarian bola secara otomatis. Jika robot tidak menemukan bola walaupun robot sudah mencari bola dengan berputar $360^{\circ}$ robot mengidentifikasi tempat yang sedang robot tempati dan berpindah tempat dengan jarak tertentu. Ketika bola ditemukan maka robot mendetekati bola sampai bola tepat di depan robot. Selanjutnya robot mengidentifikasi arah yang sedang dituju terhadap bola, apakah ke daerah sendiri atau daerah lawan dengan berputar di tempat secara berlahan dengan mencari warna gawang lawan. Jika robot menghadap ke arah daerah sendiri maka robot memutari bola hingga menuju ke arah lawan, jika sudah menuju arah lawan maka robot mendorong bola menuju gawang lawan.

Jika di depan robot terdapat halangan maka robot menggiring bola ke samping halangan yang lebih terbuka atau tidak terhalang. Selain itu robot juga dapat mengindentifikasi daerah luar lapangan. Robot berputar kanan hingga robot tidak menghadap ke daerah luar lapangan. Robot terus bergerak hingga bola berada di daekat gawang lawan.

\section{DIAGRAM BLOK RANCANGAN}

Berdasarkan deskripsi konsep robot yang dirancang memiliki dua macam input. Input pertama adalah pengaktif untuk mengaktifkan atau mematikan sistem. Input kedua adalah kamera untuk menangkap gambar. Gambar yang diterima dari kamera diolah oleh pemroses untuk menentukan pergerakan motor DC kanan, motor DC kiri, dan motor DC belakang. Diagam blok robot dapat dilihat pada Gambar 2.

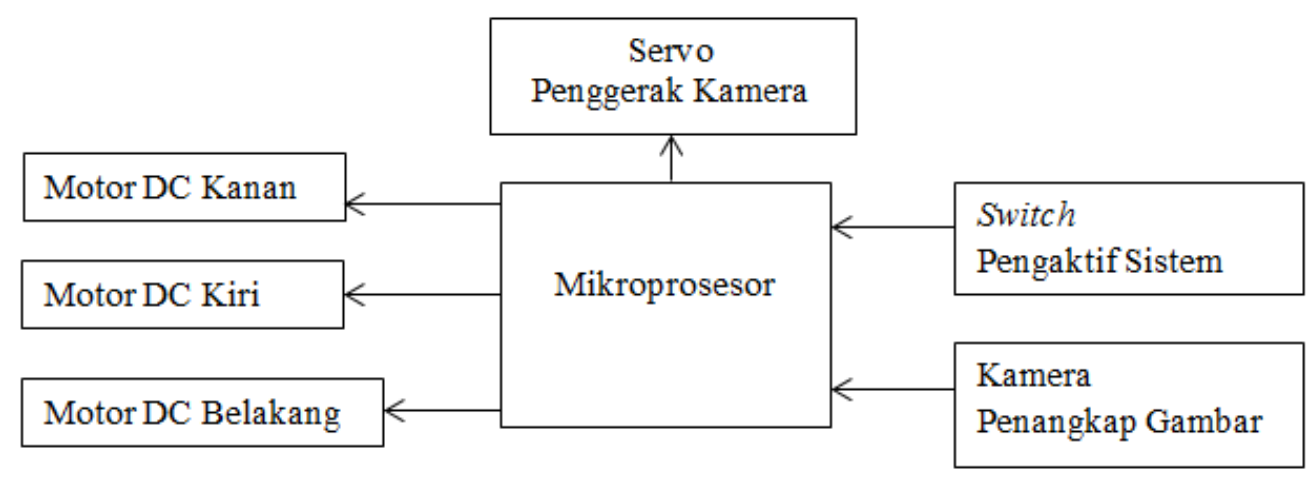

- Gambar 2. Diagram Blok Robot

\section{Catu Daya}

Catu daya adalah suatu perangkat elektronik yang berfungsi untuk mensuplai energi listrik ke suatu rangkaian elektronik lain. Salah satu catu daya yang sering ditemui adalah baterai. Berikut beberapa jenis-jenis baterai: Zinc-carbon, Li-ion (lithium-ion), dan Li-Po(Lithium Polymer).

\section{Kamera}

Kamera adalah suatu alat yang berfungsi untuk menangkap suatu gambar yang kemudian dapat menghasilkan data dari gambar tersebut sehingga dapat disimpan ke dalam memori. Sebuah kamera memiliki komponen utama lensa dan image sensor. Image sensor ini berfungsi untuk membaca cahaya yang dipantulkan benda dengan sangat cepat yang kemudian dapat menghasilkan suatu data yang dapat dibaca oleh perangkat lain seperti komputer untuk diproses. 


\section{Driver motor DC}

Driver motor DC adalah suatu alat yang digunakan untuk mengontrol menyalakan, mematikan, mengontrol arah putaran (searah jarum jam atau berlawanan arah jarum jam) dan kecepatan dari suatu motor DC. Driver motor DC biasa digunakan untuk pemrograman yang menggunakan pemroses yang hanya dapat menghasilkan output dengan arus yang kecil. Driver motor DC dapat berguna untuk mengubah arus yang kecil tersebut dan mengubahnya menjadi arus yang lebih besar sehingga dapat memutar motor.

\section{Motor Servo}

Motor Servo adalah suatu motor yang dapat bergerak searah jarum jam atau berlawanan arah jarum jam yang memungkinkan servo dapat berhenti pada suatu sudut tertentu. Servo ada dua macam yaitu servo continuous yang dapat terus berputar $360^{\circ}$ seperti motor dan servo discontinuous yang tidak dapat berputar $360 \%$ memiliki batasan putar tertentu. Motor servo dikendalikan dengan memberi sinyal pulse wide modulation (PWM) yang sesuai dengan lebar pulsa dan pulse cycle servo.

\section{Motor DC}

Motor DC adalah suatu motor yang menggunakan tegangan DC sebagai sumber penggeraknya. Motor DC terdiri dari dua bagian utama yaitu stator dan rotor. Stator adalah bagian yang tidak berputar yang terdapat magnet di sisinya. Rotor atau kumparan jangkar adalah bagian yang berputar. Ketika rotor terdapat tegangan maka rotor berputar karena timbul gaya gerak listrik

\section{Roda Omni}

Roda omni adalah sebuah roda yang di sekelilingnya terdapat beberapa roda lagi berbentuk tabung oval yang dipasang sedemikian rupa sehingga memungkinkan suatu alat bergerak ke segala arah. Roda pada bagian pinggir roda ini terbuat dari bahan - bahan yang berbeda. Bahan yang sering digunakan untuk roda bagian pinggir roda ini adalah plastik dan karet. Gambar contoh roda omni dapat dilihat pada gambar 3.

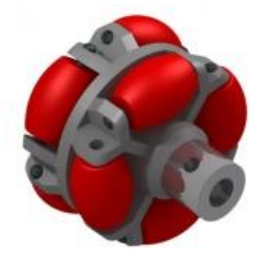

- Gambar 3. Roda Omni

\section{Penurun Tegangan}

Penurun tegangan digunakan untuk mengubah tengangan yang lebih tinggi ketegangan yang lebih rendah. Penurunan tegangan ini biasanya digunakan agar satu sumber catu daya dapat digunakan untuk berbagai rangkaian elektronik yang membutuhkan tegangan atau arus yang berbeda-beda.

\section{Mikroprosesor}

Mikroprosesor adalah prosesor komputer yang menggabungkan fungsi pusat prosesor unit komputer pada sebuah sirkuit terpadu atau beberapa sirkuit terpadu. Mikroprosesor adalah komponen serba guna, perangkat yang dapat diprogram yang menerima data digital sebagai input, memprosess data digital sesuai instruksi pada memori, dan memberikan hasil sebagai output.

\section{Open Source Computer Vision (OpenCV)}

OpenCV adalah sebuah library bebas yang dapat digunakan pada bahasa pemrograman $\mathrm{C}++, \mathrm{C}$, Python, dan Java yang mensuport sistem operasi windows, linux, mac OS, iOS, dan Android yang difokuskan untuk pengolahan citra. OpenCV berisi algoritma-algoritma yang memudahkan untuk mengenali isi suatu gambar [2, 3].

\section{Raspberry Pi Tipe B}

Raspbery Pi Tipe B adalah sebuah single board computer [4] yang pada perancangan ini digunakan untuk mengontrol sistem secara keseluruhan mulai dari mengontrol kamera, servo, dan motor.

\section{Kamera Webcam Logitech C170}

Kamera ini digunakan untuk menangkap gambar yang kemudian diproses oleh pemroses. Kamera ini memiliki ketajaman Gambar 1,3 megapixel dan memiliki kabel USB untuk transfer data 


\section{Servo FUTABA $\mathbf{S 3 0 0 3}$}

Servo Futaba S3003 pada rancangan digunakan untuk menggerakkan kamera pada robot. Servo ini bekerja pada tegangan 4,8-6V, torsi pada tegangan $4,8 \mathrm{~V}$ adalah $3,2 \mathrm{~kg} . \mathrm{cm}$ dan $4,1 \mathrm{~kg} . \mathrm{cm}$ pada tegangan $6 \mathrm{~V}$, mengkonsumsi arus sebesar7,2 mA-8 mA, memiliki lebar pulsa 1000-2000us, menerima sinyal setiap 20ms.

\section{Baterai LiPo5600 mAH 2 Cell 50-100C}

Baterai LiPo 5600 mAH 2 cell digunakan untuk memberi daya ke robot agar dapat bekerja. Spesifikasi baterai Lipo yang digunakan adalah dua cell yang menyatakan baterai dapat mensuplai tegangan sebesar $2 \mathrm{x}$ $3,7 \mathrm{~V}(1$ cell $=3,7 \mathrm{~V})=7,4 \mathrm{~V}$ spesifikasi $5600 \mathrm{mAH}$ menyatakan kapasitas baterai per jam, sedangkan 50C adalah faktor pengali kapasitas baterai per jam untuk mendapatkan total kapasitas baterai dapat digunakan.

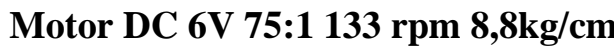

Motor DC 6V 75:1 $133 \mathrm{rpm}$ digunakan untuk menggerakkan robot ke suatu arah tertentu. Jumlah Motor DC yang digunakan adalah tiga buah. Motor DC yang digunakan pada robot yang dirancang adalah motor DC 6V 75:1 $133 \mathrm{rpm}$. Torsi maksimal motor DC ini adalah 8,8 kg-cm. Motor DC ini dipilih karena robot yang dirancang tidak terlalu membutuhkan kecepatan tetapi lebih membutuhkan torsi untuk mengangkat beban robot yang cukup berat.

\section{Regulator LM7905}

Regulator LM7905 ini digunakan untuk memberi tegangan ke motor driver L298. Regulator ini dapat mengubah tegangan hingga $25 \mathrm{~V}$ dan menghasilkan arus hingga 1,5 ampere. Arus dan tegangan ini cukup untuk memberi daya pada IC motor driver DC L298 yang hanya membutuhkan tegangan input 4,5 volt- 7volt dengan arus maksimal $70 \mathrm{~mA}$.

\section{Ultimate Battery Eliminator Circuit Turnigy 15A 5-6V (UBEC)}

$U B E C$ berguna untuk menurunkan tegangan DC yang besar ke tegangan DC yang lebih kecil. UBEC biasanya terbatas untuk menurunkan tegangan pada teganan 4 cell dan hanya mengeluarkan tegangan antara 5$6 \mathrm{~V}$ tetapi $U B E C$ memiliki keluaran arus yang besar. $U B E C$ yang dipilih adalah $U B E C$ Turnigy $15 \mathrm{~A} 5-6 \mathrm{~V}$.

\section{Modul Regulator LM2596}

Regulator ini digunakan untuk menurunkan tegangan dari baterai ke Raspberry Pi. LM2596 digunakan karena dapat menghasilkan arus maksumal 3A, tegangan DC input 1,5-37 volt dan tegangan DC output 5 volt yang cukup untuk menjalankan Raspberry Pi yang membutuhkan tegangan 5 volt dan arus maksimal 1,2A. Gambar skematik rangkaian dapat dilihat pada gambar 4.

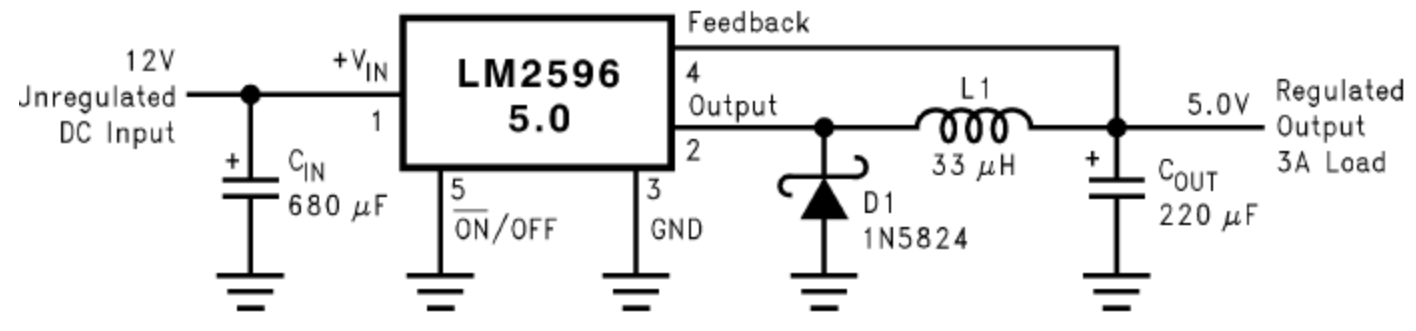

- Gambar 4. Skematik LM2596 ke 5V

\section{Modul Motor Driver L298}

Modul motor driver ini digunakan untuk mengendalikan gerakan motor. L298 membutuhkan tegangan logic supply $4,8 \mathrm{~V}-7 \mathrm{~V}$ dengan arus maksimal $70 \mathrm{~mA}$ untuk IC 1298, input voltage dan enable voltage $0,3 \mathrm{~V}-7 \mathrm{~V}$ dengan arus maksimal $100 \mathrm{uA}$, supply voltage hingga $50 \mathrm{~V}$ dengan arus keluaran maksimal hingga $3 \mathrm{~A}$ ketika kedua enable digabungkan. Tegangan pada logic supply voltage berguna untuk mengaktfikan IC L298 dan supply voltage digunakan untuk memberi tegangan pada motor DC. Gambar sketmatik rancangan motor driver dapat dilihat pada gambar 5 . 


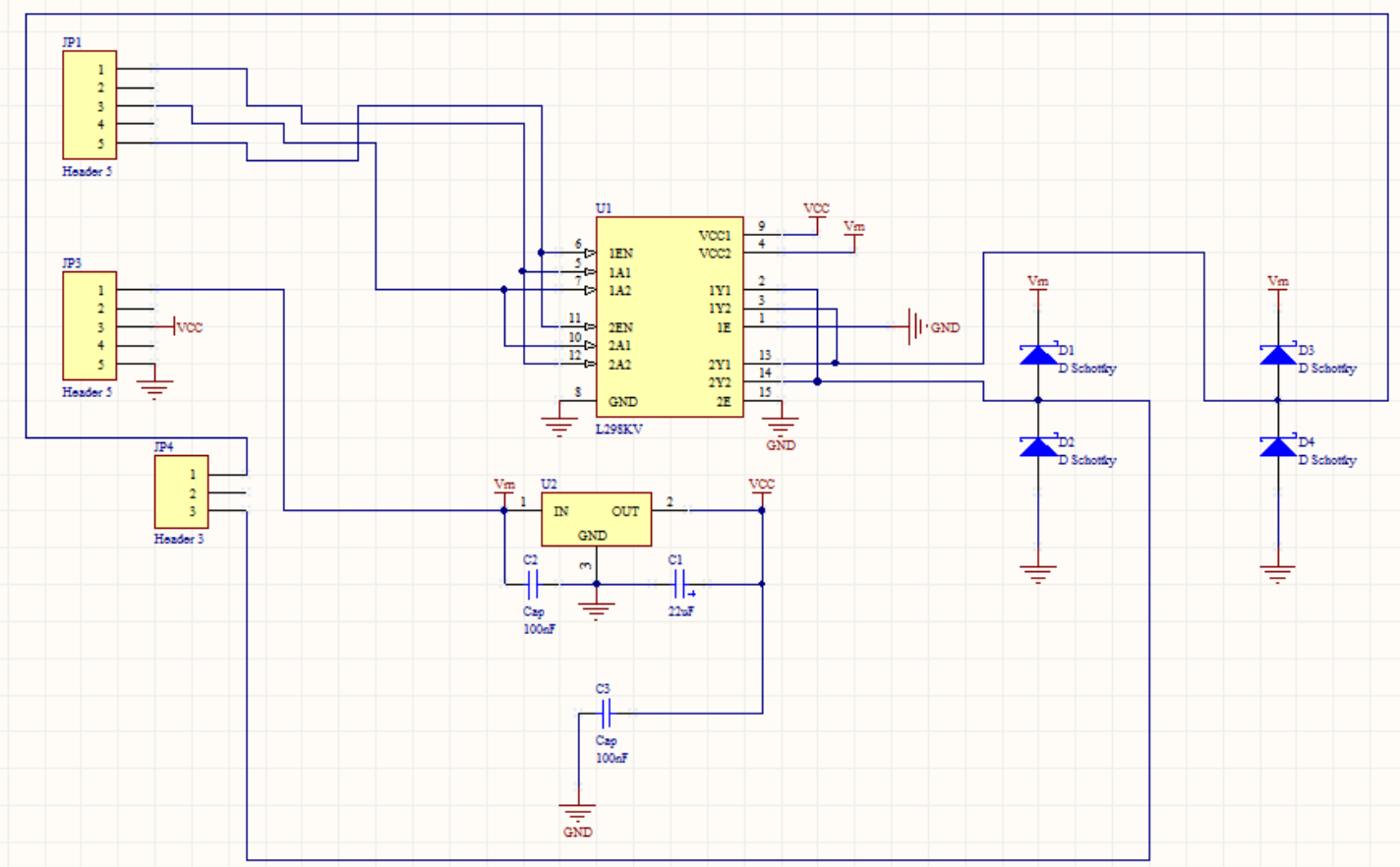

- Gambar 5. Skematik Rancangan Motor Driver L298

\section{Realisasi Modul Badan Robot}

Badan mekanik robot terbuat dari bahan acrylic dengan tebal $5 \mathrm{~mm}$. Desain bentuk robot dirancang dengan menggunakan aplikasi Autodesk Inventor yang kemudian per bagian robot dicetak dengan suatu mesin laser khusus. Bagian utama robot terdiri dari tiga bagian yaitu bagian bawah, bagian tengah, dan bagian atas.

Bagian bawah robot bebentuk segi enam sama sisi dengan diameter 25,4 cm. Bagian bawah ini untuk meletakkan ketiga motor driver, ketiga motor DC dan capit. Bagian tengah robot berbentuk segi enam sama sisi dengan diameter $25,4 \mathrm{~cm}$ dan terdapat sebuah lobang berbentuk lingkaran dengan diameter $2 \mathrm{~cm}$ untuk tempat kabel yang menghubungkan modul-modul dari bagian bawah robot ke modul-modul bagian atas dan tengah robot. Bagian tengah ini untuk meletakkan Raspberry Pi, UBEC, dan modul regulator LM2596.

Bagian atas robot berbentuk setengah segi enam sama sisi dengan diameter $25,4 \mathrm{~cm}$. Bagian atas ini dipasang pada setengah bagian depan tengah robot. Bagian atas ini digunakan untuk tempat meletakkan baterai dan penopang servo yang terbuat dari acrylic. Pada penopang servo terdapat servo yang dipasang seperti Gambar 3.14. Pada bagian servo yang beputar terdapat penopang antara servo dan kamera yang terbuat dari acrylic. Gambar keseluruhan dapat dilihat pada gambar 1.

\section{Realisasi Program Pengendali Motor Driver DC}

Realisasi program pengendali motor driver DC menggunakan sebuah library yang disebut WiringPi dan bahasa pemrograman $\mathrm{C}++$ yang dapat langsung dibuat di LXterminal pada Raspberry Pi. WiringPi adalah sebuah library yang memudahkan pengguna untuk mengakses pin-pin GPIO pada Raspberry Pi. Informasiinformasi WiringPi dapat dilihat pada alamat website http://WiringPi.com/. Untuk mengontrol motor, Raspberry Pi harus dapat mengirim tiga sinyal dari tiga pin inputloutput (GPIO) ke satu motor driver. Dua pin dihubungkan ke kedua bagian input voltage motor driver dan satu pin ke bagian enable voltage dari motor driver. Untuk mengontrol keluaran input/output pin-pin pada Raspberry Pi digunakan suatu program dengan bahasa pemrograman $\mathrm{C}++$ dan library khusus yang memudahkan mengakses alamat dan mengatur keluaran pin-pin GPIO pada Raspberry Pi.

\section{Realisasi Program Pengendali Motor Servo}

Realisasi program pengendali servo didapat dengan menggunakan suatu software yaitu software servoblaster. Dengan adanya servoblaster dimungkinkan untuk mengatur keluaran pin dengan arus tertentu untuk membentuk suatu pulsa. Untuk penggunaanya biasanya harus menuliskan perintah langsung pada LXterminal oleh karena itu agar dapat mengendalikan motor servo melalui bahasa pemrograman $\mathrm{C}++$ digunakan perintah system. Cara kerja servo adalah menerima pulsa dengan lebar pulsa tertentu setiap waktu tertentu. Sebagian besar servo bekerja pada lebar pulsa 1000us-2000us setiap 20ms.

\section{Realisasi Program Pengolah Gambar}

Realisasi pengolahan gambar menggunakan suatu library yang disebut OpenCV. Untuk mempelajari fungsi-fungsi pada OpenCV dapat dilihat pada http://opencv.org/documentation.html atau 
http://docs.opencv.org/2.4/doc/ tutorials/tutorials.html. OpenCV memiliki sangat banyak perintah fungsi yang memudahkan untuk mengolah gambar oleh karena itu untuk mempercepat pembuatan sistem perancang menggunakan suatu program yang didapat dari internet buatan Kyle Hounslow yang perancang modifikasi agar dapat digunakan pada Raspberry Pi yang digunakan pada rancangan. Fungsi-fungsi yang terdapat pada program pengolahan gambar adalah fungsi drawobject, morphos, trackfilteredobject, dan utama. Program Kyle Hounslow dapat dilihat pada https://github.com/kylehounslow/ opencv-tuts/blob/master/object-tracking-tu t/objectTrackingTut.cpp.

\section{Penentuan Rentang Warna pada Model Warna HSV}

Jenis model warna yang digunakan pada program adalah Hue Saturation Value (HSV) karena model warna ini lebih mudah diganti-ganti dan dimengerti dalam pencarian nilai warna karena tinggal memasukan nilai hue sesuai warna yang dilihat oleh mata kemudian tinggal mengatur saturation dan value sesuai dengan cerahgelap gambar. Hue menyatakan warna asli/dasar dari gambar yang dilihat. Saturation menyatakan kecerahan gambar dari putih ke warna dasar. Value menyatakan seberapa gelap gambar dari hitam ke warna dasar. Pada program terdapat fungsi untuk kalibrasi warna. Pada fungsi seluruh warna hue dibagi menjadi 8 bit (0-255), begitu juga dengan saturation dan value. Selain itu untuk mendapat rentang dari suatu warna setiap hue dibagi menjadi hue untuk nilai paling rendah dan hue untuk warna paling tinggi yang ingin didapat begitu juga untuk saturation dan value.

Hal paling penting dalam kalibrasi warna kita harus mengetahui terlebih dahulu rentang dari warna dasar. Model warna HSV digambarkan dalam bentuk tabung dengan keliling lingkaran yang menyatakan warnawarna dasar yang disebut Hue, tinggi tabung yang menyatakan semakin hitam(gelap) atau semakin menuju warna dasar yang disebut Saturation, dan dari titik tengah lingkaran yang terang(putih) atau semakin menuju warna dasar. Rentang warna dasar ini dapat dilihat pada https://en.wikipedia.org/wiki/HSL_and_HSV\#From_HSV [27]. Dari hasil perhitungan dari tabung warna ke 8 bit data yaitu (batas rentang warna yang dicari)/360*256 diperoleh nilai dasar hue seperti pada Gambar 6 .

\begin{tabular}{|l|l|}
\hline Warna & Batas warna hue \\
\hline Merah & $233-255$ dan $0-6$ \\
\hline Jingga & $6-35$ \\
\hline Kuning & $35-63$ \\
\hline Hijau & $63-105$ \\
\hline Cyan & $105-148$ \\
\hline Biru & $148-191$ \\
\hline Magenta & $191-233$ \\
\hline
\end{tabular}

- Gambar 6. Tabel Nilai Rentang Warna Dasar Hue Dalam 8 bit

\section{Fungsi Drawobject}

Potongan fungsi ini digunakan untuk membuat tanda/gambar ke tampilan window hasil tangkapan kamera terhadap warna benda yang ingin didapat. Pada rancangan fungsi yang digunakan adalah fungsi line untuk menggambar garis, fungsi circle untuk menggambar lingkaran, dan fungsi putText untuk menggambar tulisan. Format syntax untuk membuat lingkaran pada OpenCV adalah circle(Mat\& img, Point center, int radius, const Scalar\& color, int thickness $=1$, int lineType $=8$, int shift $=0$ ) Contoh penggunaan fungsi circle pada rancagan adalah circle (frame, Point(x,y), 20, Scalar(0,255,0), 2); Circle merupakan fungsi untuk menggambar lingkaran, frame adalah tempat yang akan digambar lingkaran, Point $(\mathrm{x}, \mathrm{y})$ adalah titik pusat lingkaran. 20 menyatakan jari-jari lingkaran, Scalar $(0,255,0)$ menyatakan warna dari $(r, g, b)$ jadi nilai yang tercantum digunakan untuk memberi warna hijau pada lingkaran, 2 terkahir menyatakan ketebalan garis lingkaran.

\section{Fungsi Morphos}

Fungsi morphos yang terdiri dari fungsi erode dan dilate. Fungsi ini digunakan untuk menghilangkan noise-noise pada hasil tangkapan gambar.

Fungsi erode adalah fungsi yang membuat suatu ukuran pixel berwarna gelap melebar dengan cara membuat dahulu sebuah kernel atau frame erode yang kemudian dibagai menjadi beberapa kotak kecil atau lingkaran kecil dengan ukuran tertentu lalu frame erode tersebut ditumpuk ke frame utama, jika di suatu kotak frame erode terdapat warna hitam hampir sebesar kotak dan dalam kotak tersebut terdapat warna putih maka warna putih diubah menjadi warna hitam untuk memenuhi kotak frame erode.

Fungsi dilate adalah fungsi yang membuat suatu ukuran pixel dari sebuah frame yang berwarna terang melebar dengan cara membuat dahulu sebuah kernel atau frame dilate yang kemudian dibagai menjadi beberapa kotak kecil atau lingkaran kecil dengan ukuran tertentu lalu frame dilate tersebut ditumpuk ke frame utama, jika 
di suatu kotak frame dilate terdapat warna putih hampir sebesar kotak dan dalam kotak tersebut terdapat warna hitam maka warna hitam diubah menjadi warna putih untuk memenuhi kotak frame erode.

\section{Fungsi Trackfilteredobject}

Fungsi ini adalah fungsi utama untuk mendeteksi titik tengah/koordinat dan luas suatu objek dari frame yang didapat. Nilai titik tengah dan luas objek ini lah yang nantinya akan digunakan untuk mengetahui letak object yang dicari. Isis utama fungsi ini adalah perintah findcontour. Perintah findcontour memiliki format penulisan : findContours(InputOutputArray image, OutputArray OfArrays contours, OutputArray hierarchy, int mode, int method); ); findContours menyatakan fungsi mencari contours, InputOutputArray image menyatakan output dan input frame yang ingin dicari contournya. OutputArrayOfArrays contours menyatakan contourcontour yang didapat dari InputOutputArray. OutputArray hierarchy menyatakan hierarchy-hierarchy pada InputOutputArray image, int mode adalah mode hierarrchy yang digunakan. Int method adalah metode contour yang digunakan.

\section{Fungsi utama}

Fungsi utama pada rancangan digunakan untuk memanggil dan menggunakan fungsi-fungsi yang telah dibuat dan berisi perintah-perintah untuk menyiapkan, mengatur, dan menangkap gambar dari kamera.

\section{REALISASI KESELURUHAN SISTEM}

Realisasi keseluruhan sistem dilakukan dengan memasang seluruh modul. Ground output baterai dihubungkan ke ground input UBEC dan VCC output baterai dihubungkan ke VCC input UBEC. Keluaran VCC output UBEC dihubungkan ke pin VS atau Vm input pada motor driver belakang, kanan, dan kiri serta ke pin VCC input Servo Futaba S3003 dan ke VCC input LM2596. Ground output UBEC dihubungkan ke ground input Motor driver belakang, kanan, dan kiri serta ground pada input LM2596. Keluaran dari VCC output LM2596 dihubungkan ke VCC input Raspberry Pi. Ground output LM2596 dihubungkan ke ground input Raspberry Pi. Setelah semua modul terpasang switch pada UBEC dipindah ke on sehingga arus dan tegangan dapat mengalir ke output UBEC dan dapat memberi daya seluruh modul yang lain. Setelah Raspberry Pi selesai booting maka program yang dirancang bekerja.

Diagram alir program untuk mengatur gerakan robot yang dirancang dapat dibagi menjadi beberapa flowchart. Flowchart yang menghubungkan antar flowchart disebut flowchart utama yang dapat dilihat pada Gambar 3.37. Flowchart lainnya adalah flowchart ganti 0, ganti 4, ganti 1/2, dan ganti 3. Flowchart utama program keseluhan robot dapat dilihat pada gambar 7.

Flowchart ganti=0 adalah flowchart algoritma untuk mengolah data berdasarkan warna bola dan menentukan arah ke flowchart lain atau menggerakan robot. Inti dari program algoritma ganti $=0$ adalah untuk mencari bola, mendekati bola, menuju tepat depan bola, dan membawa bola menuju gawang lawan jika bola sudah tepat depan robot. Flowchart ganti $=0$ dapat dilihat pada gambar 8.

Flowchart ganti $=4$ adalah flowchart algoritma untuk mengolah data berdasarkan warna halangan dan menentukan arah ke flowchart lain atau menggerakan robot. Inti dari program algoritma ganti $=4$ adalah untuk menghindari satu atau dua halangan ke daerah yang tidak terhalang. Flowchart ganti $=4$ dapat dilihat pada gambar 9.

Flowchart ganti=1/2 adalah flowchart algoritma untuk mengolah data berdasarkan warna gawang lawan/sendiri dan menentukan arah ke flowchart lain atau menggerakan robot. Inti dari program algoritma ganti $=1$ atau ganti $=2$ adalah untuk menuju gawang lawan jika sudah mendapatkan bola dan ganti $=1$ atau 2 untuk melakukan perpindahan posisi di lapangan jika tidak menemukan bola di daerah lainnya. Flowchart ganti $=1$ atau ganti 2 dapat dilihat pada gambar 10 . 


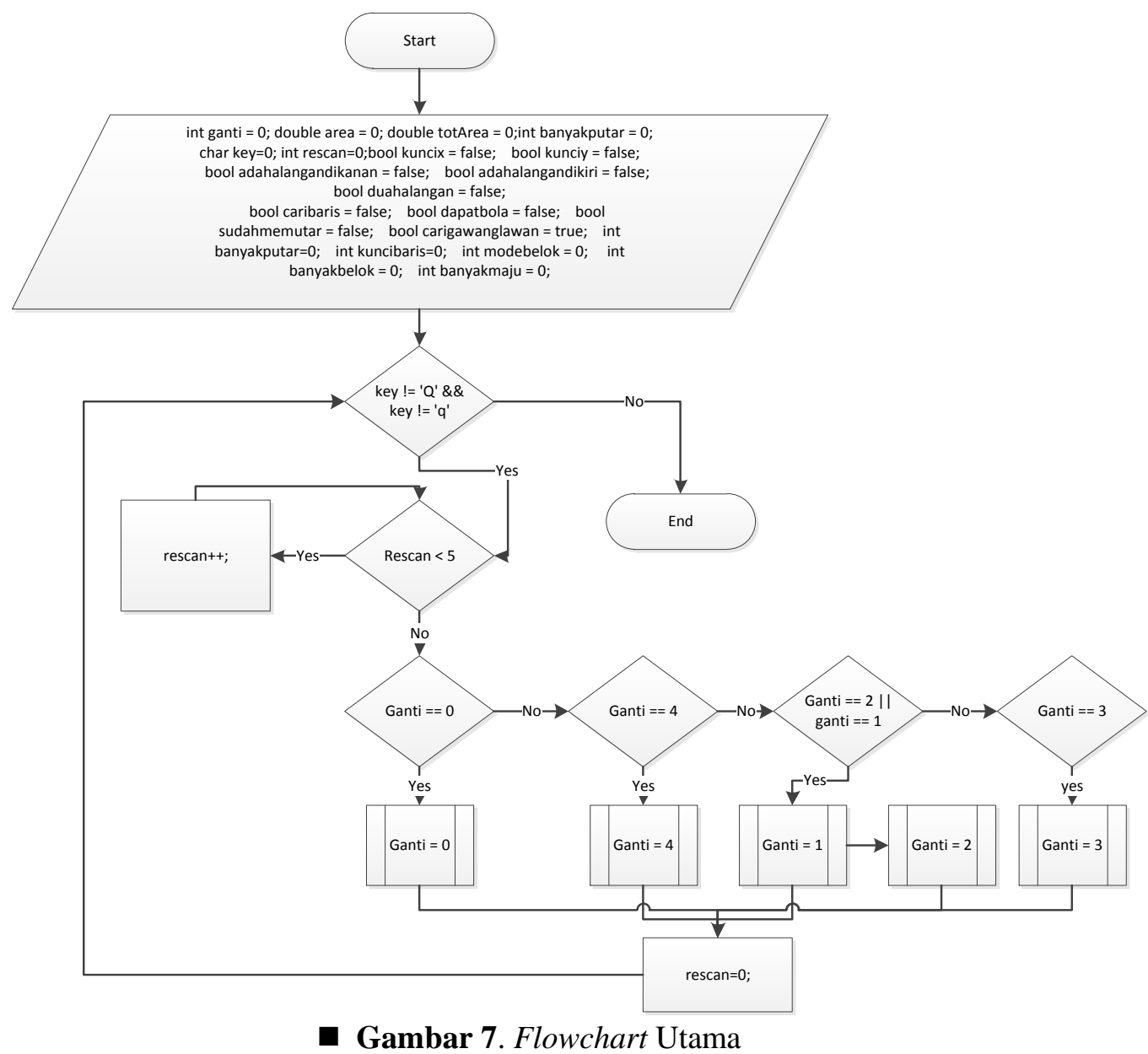

Flowchart ganti=3 adalah flowchart algoritma untuk mengolah data berdasarkan warna lapangan dan menentukan arah ke flowchart lain atau menggerakan robot. Inti dari program algoritma ganti $=3$ adalah untuk menjaga robot tetap di dalam lapangan dan mencegah robot berputar ditempat terus menerus karena tidak menemukan bola. Flowchart ganti = 3dapat dilihat pada gambar 11.

\section{Pengujian Gerak Robot}

Pengujian dilakukan untuk mengetahui apakah dapat menggerakan robot maju, diam, dan berputar di tempat kanan/kiri. Pengujian dilakukan dengan seluruh modul telah terpasang dengan bantuan program pengujian gerak. Tabel hasil pengujian dapat dilihat pada Tabel 1. Dari hasil pengujian dapat dinyatakan seluruh gerakan pada rancangan dapat dilakukan yaitu maju, berputar tempat kanan/kiri, dan diam.

Tabel 1 Hasil Pengujian Gerak Robot

\begin{tabular}{|c|c|c|c|c|c|c|c|}
\hline \multirow{3}{*}{\multicolumn{2}{|c|}{$\begin{array}{c}\text { Motor } \\
\text { Belakang }\end{array}$}} & \multirow{2}{*}{\multicolumn{2}{|c|}{$\begin{array}{l}\text { Motor } \\
\text { Kanan }\end{array}$}} & \multirow{2}{*}{\multicolumn{2}{|c|}{$\begin{array}{c}\text { Motor } \\
\text { Kiri }\end{array}$}} & \multirow{4}{*}{ Pergerakan yang dihasilkan } & \multirow{4}{*}{$\begin{array}{c}\text { Digunakan/ } \\
\text { tidak }\end{array}$} \\
\hline & & & & & & & \\
\hline & pin & \multicolumn{2}{|c|}{ Input pin } & \multicolumn{2}{|c|}{ Input pin } & & \\
\hline 2 & 3 & 13 & 14 & 10 & 11 & & \\
\hline 0 & 0 & 0 & 0 & 0 & 0 & Diam & Ya \\
\hline 0 & 0 & 1 & 0 & 0 & 1 & Maju lurus & $\mathrm{Ya}$ \\
\hline 0 & 1 & 0 & 1 & 0 & 1 & Putar ditempat ke kanan/searah jarum jam & Ya \\
\hline 1 & 0 & 1 & 0 & 1 & 0 & Putar ditempat ke kiri/berlawanan searah jarum jam & $\mathrm{Ya}$ \\
\hline
\end{tabular}




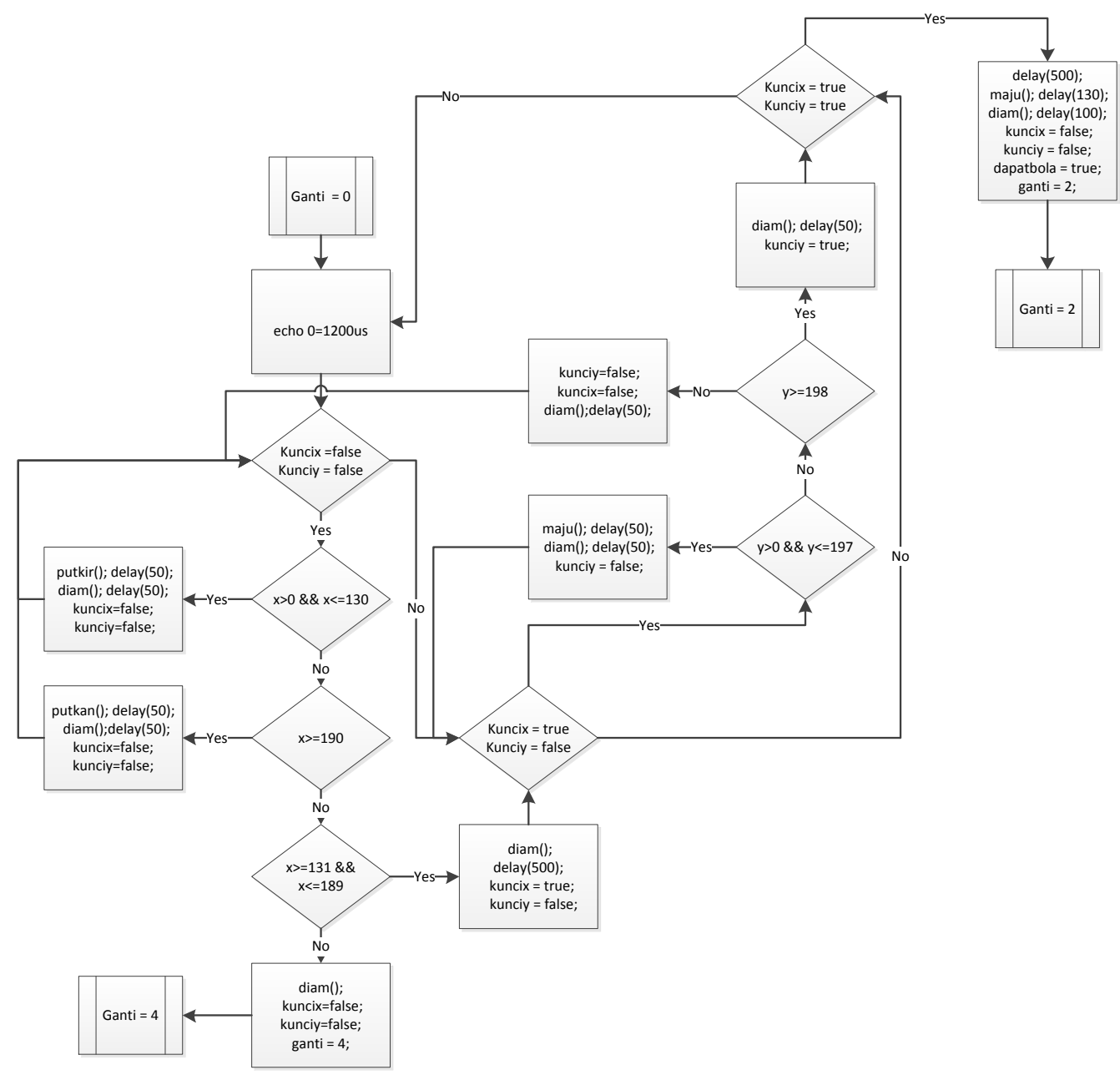

- Gambar 8. Flowchart Ganti = 0

\section{Pengujian dan Analisis Seluruh Sistem}

Pengujian seluruh sistem dilakukan untuk mengetahui apakah hasil rancangan dapat sesuai dengan tujuan rancangan atau tidak. Pengujian seluruh sistem dilakukan dengan beberapa tahap. Tahap berpindah tempat adalah Pengujian berpindah tempat tanpa bola dan halangan. Tabel Hasil pengujian dapat dilihat pada tabel 3.

\section{Pengujian dan Analisis Kalibrasi Warna}

Pengujian bertujuan untuk menentukan apakah semua warna yang digunakan dapat dibedakan dan mendapat nilai HSV yang harus di-input ke program untuk dapat membaca warna yang dicari. Pengujian dilakukan dengan meletakkan seluruh warna berdempetan hingga dapat dilihat semua oleh kamera dan menggunakan sebuah software yang dapat diubah nilai-nilai HSV nya. Tabel hasil pengujian dapat dilihat pada Tabel 2. Dari hasil pengujian dapat dinyatakan sistem dapat membaca dan membedakan warna-warna yang ditentukan dengan baik.

Tabel 3 Hasil Pengujian Serluruh Sistem Berpindah Daerah

\begin{tabular}{lllll}
\hline No & Posisi & $\begin{array}{l}\text { Berhasil ke } \\
\text { gawang lawan }\end{array}$ & $\begin{array}{l}\text { Berhasil ke } \\
\text { gawang Sendiri }\end{array}$ & $\begin{array}{l}\text { Berhasil ke gawang } \\
\text { lawan lagi }\end{array}$ \\
\hline 1 & Dekat gawang lawan & ya & ya & Ya \\
2 & Dekat Gawang Sendiri & ya & ya & Ya \\
\hline
\end{tabular}

Dari hasil pengujian pada Tabel 3 dapat dinyatakan robot dapat berpindah dari daerah dekat gawang lawan ke daerah dekat gawang sendiri untuk mencari bola pada daerah dekat gawang lawan dan dekat daerah gawang sendiri dengan baik tanpa halangan. 


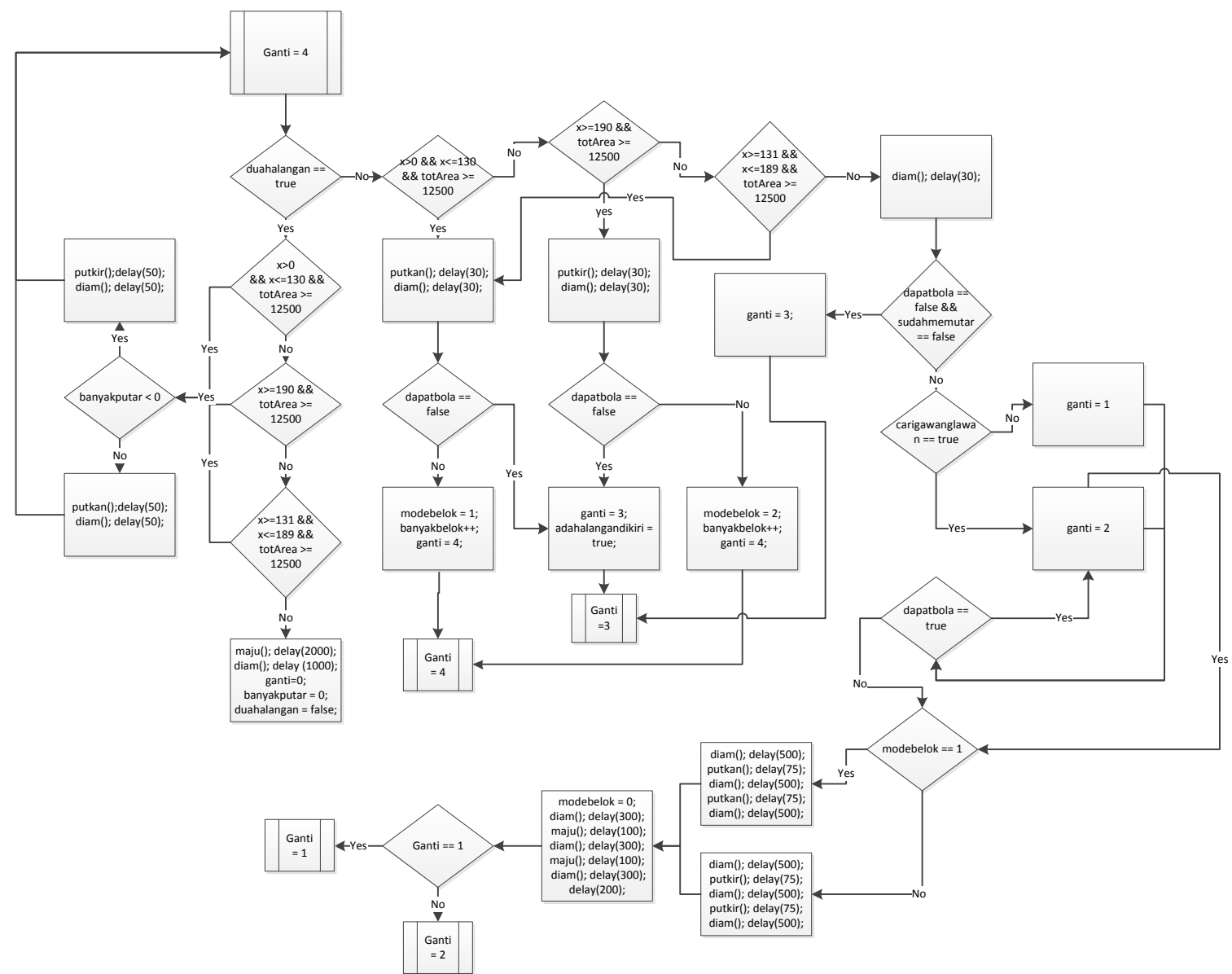

-Gambar 9. Flowchart Ganti $=4$

- Tabel 2 Pengujian Kalibrasi Warna

\begin{tabular}{|c|c|c|c|c|c|c|c|}
\hline Warna & H max & $\mathrm{H} \min$ & $\mathrm{S} \max$ & $S \min$ & $\mathrm{V} \max$ & $\mathrm{V} \min$ & Tampilan \\
\hline \multicolumn{7}{|c|}{ Gambar asli tangkapan kamera } & \\
\hline Jingga & 0 & 17 & 0 & 206 & 240 & 255 & \\
\hline Kuning & 18 & 62 & 101 & 109 & 65 & 204 & \\
\hline Hijau & 63 & 103 & 65 & 255 & 65 & 204 & \\
\hline Cyan & 104 & 148 & 108 & 255 & 228 & 255 & \\
\hline Magenta & 149 & 226 & 142 & 223 & 236 & 255 & \\
\hline
\end{tabular}




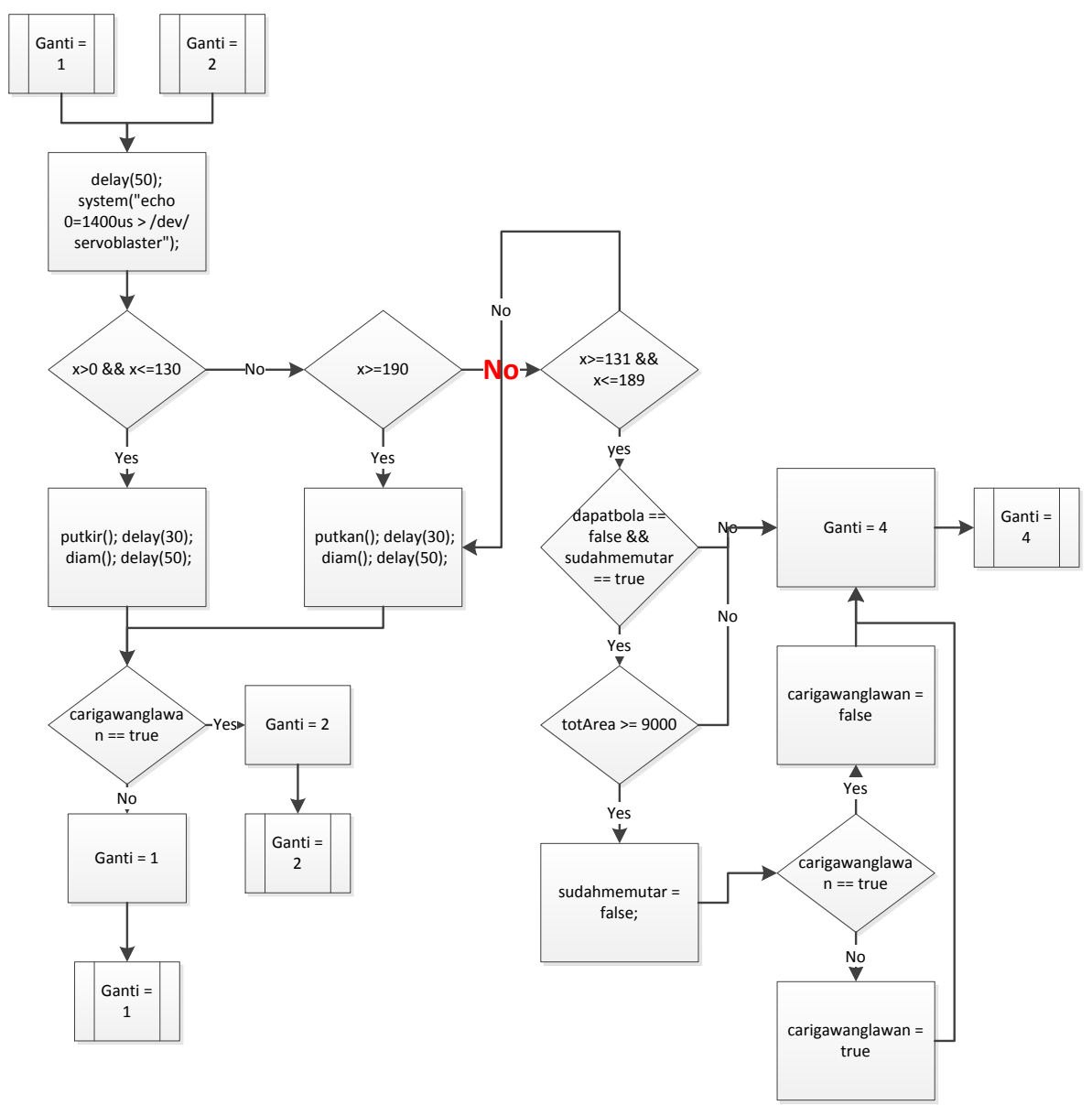

Gambar 10. Flowchart Ganti $=1$ atau Ganti 2

Pengujian selanjutnya adalah pengujian untuk menghindari halangan. Dari hasil pengujian pada Tabel 4 dapat dinyatakan robot berhasil menghindari halangan ke daerah yang lebih tidak terhalang oleh halangan.

Tabel 4 Hasil Pengujian Menghindari Halangan

\begin{tabular}{lllll}
\hline $\begin{array}{l}\text { Uji } \\
\text { ke }\end{array}$ & $\begin{array}{l}\text { Halangan } \\
\text { satu }\end{array}$ & $\begin{array}{l}\text { Halangan } \\
\text { dua }\end{array}$ & $\begin{array}{l}\text { Gerak robot setelah halangan 1 } \\
\text { tertangkap }\end{array}$ & Gerak robot setelah halangan 2 tertangkap \\
\hline 1 & - & - & Putar kanan & Tidak diuji \\
2 & kiri & - & Putar kiri & Tidak diuji \\
3 & tengah & - & Putar kanan & Tidak diuji \\
4 & kiri & kanan & Putar kiri & Putar kiri \\
5 & tengah & kanan & Putar kanan & Putar kanan \\
6 & tengah & tengah & Putar kanan & Tidak diuji \\
\hline
\end{tabular}

Pengujian selanjutnya adalah pengujian untuk mendekati bola, menghindari halangan, dan menggiring bola ke gawang lawan. Dari hasil pengujian tabel 5 dapat dinyatakan rancangan dapat memenuhi tujuan rancangan yaitu membuat robot yang dapat mencari bola, mendekati bola, dan menjauhkan bola dari daerah lapangan/gawang sendiri ke arah daerah lapangan/gawang lawan dengan memperhatikan juga posisi halangan yaitu dengan cara dapat menghindari halangan ke ruang yang lebih luas dan posisi robot di lapangan dengan cara dapat berpindah-pindah tempat dari daerah dekat gawang sendiri ke daerah dekat gawang lawan dan sebaliknya.

- Tabel 5 Hasil Pengujian Mendekati, Menghindari, dan Menggiring Bola ke Gawang Lawan

\begin{tabular}{|c|c|c|c|c|}
\hline Uji ke & $\begin{array}{l}\text { Memasukan ke } \\
\text { Capit }\end{array}$ & $\begin{array}{l}\text { Menghindari } \\
\text { Halangan }\end{array}$ & $\begin{array}{l}\text { Menggiring Bola ke } \\
\text { Arah Lawan }\end{array}$ & $\begin{array}{l}\text { Menggiring Bola Menempel ke } \\
\text { Tiang Gawang }\end{array}$ \\
\hline 1 & Berhasil & Berhasil & Berhasil & Berhasil \\
\hline 2 & Berhasil & Berhasil & Berhasil & Tidak \\
\hline 3 & Berhasil & Berhasil & Berhasil & Tidak \\
\hline
\end{tabular}




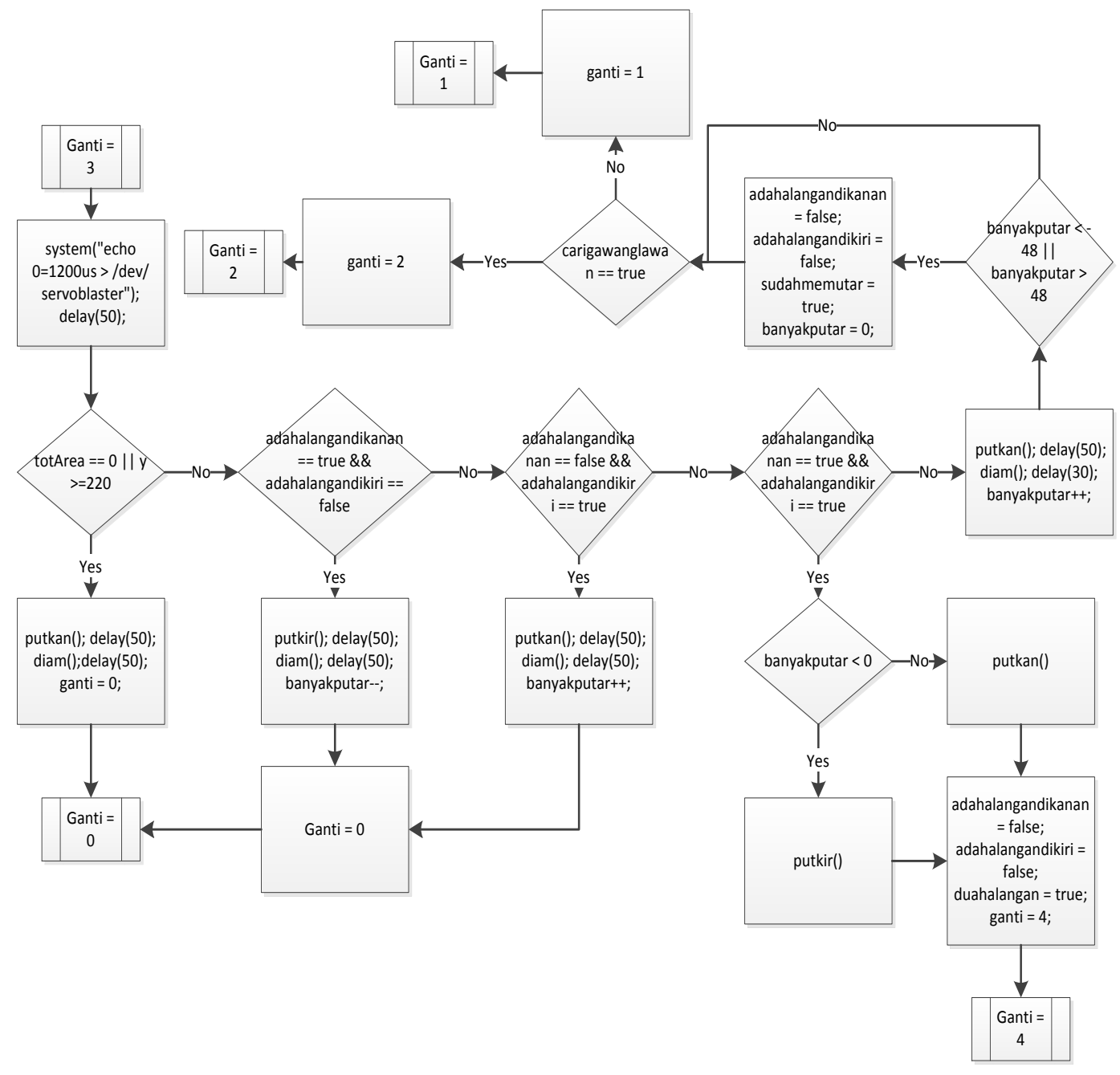

- Gambar 11. Flowchart ganti $=3$

\section{KESIMPULAN DAN SARAN}

Kesimpulan dari hasil pengujian keseluruhan rancangan adalah seluruh tujuan rancangan berhasil tercapai, pada kondisi robot sudah mendapat bola dan sedang menuju gawang lawan, robot berhasil menghindari halangan, robot membutuhkan waktu yang lama atau terkadang tidak dapat dideteksi saat mendeteksi object, robot berhasil menggiring bola ke gawang lawan pada tahap pengujian mendekati, menghindari, dan menggiring bola tetapi bola terkadang terlepas, dan robot berhasil berpindah tempat jika tidak menemukan bola.

Saran yang dapat diberikan untuk pengembang maupun pengguna rancangan adalah

- Menambahkan algoritma program untuk mengecek bola bersamaan menggiring bola ke gawang lawan

- Menggunakan sensor untuk mengukur intensitas cahaya dan melakukan perhitungan untuk mendapatkan perbandingan nilai intensitas cahaya dan perubahan nilai warna.

- Melakukan percobaan untuk mendapatkan nilai delay yang paling efesien untuk gerak robot.

- Menggunakan kamera dengan sudut pandang yang dapat mencakup badan robot keseluruhan.

- Menambahkan lawan robot yang dapat bergerak juga.

[1] Dikti Kemdikbud. Kontes Robot Sepak Bola Indonesia (KRSBI) 2014 RoboSoccer Humanoid League Kid Size. Eindhoven: Robocup Soccer Team, 2013.

[2] Itseez, "Documentation", 2015.

Internet: http://opencv.org/documentation.html. [19 September 2015,]

[3] Opencv dev team, "OpenCV Tutorial", 2015.

Internet: http://docs.opencv.org/2.4/doc/tutorials/tutorials.html. [20 September 2015]

[4] Wiring Pi, "Software PWM library", 2015.

Internet: https://projects.drogon.net/raspberry-pi/wiringpi/software-pwm-library/. [25 September 2015] 